\title{
Institutional Excellence in the Egyptian and Saudi Federations of Football in View of European Model of Excellence EFQM "A Comparative Study"
}

\author{
Mohamed Soliman Mohamed Ghreeb ${ }^{1, *}$, Ahmed Mohamed Abdelkader ${ }^{1}$, \\ Sameer Mohammed Sayyd ${ }^{2}$ \\ ${ }^{1}$ Faculty of Physical Education, University of Port said, Egypt \\ ${ }^{2}$ Faculty of Education, Sports Science Department, Taibah University, Madinah 41411, Saudi Arabia
}

Received June 15, 2021; Revised July 19, 2021; Accepted August 22, 2021

\section{Cite This Paper in the following Citation Styles}

(a): [1] Mohamed Soliman Mohamed Ghreeb, Ahmed Mohamed Abdelkader, Sameer Mohammed Sayyd, "Institutional Excellence in the Egyptian and Saudi Federations of Football in View of European Model of Excellence EFQM "A Comparative Study"," International Journal of Human Movement and Sports Sciences, Vol. 9, No. 5, pp. 993 - 1003, 2021. DOI: 10.13189/saj.2021.090521.

(b): Mohamed Soliman Mohamed Ghreeb, Ahmed Mohamed Abdelkader, Sameer Mohammed Sayyd (2021). Institutional Excellence in the Egyptian and Saudi Federations of Football in View of European Model of Excellence EFQM "A Comparative Study". International Journal of Human Movement and Sports Sciences, 9(5), 993 - 1003. DOI: 10.13189/saj.2021.090521.

Copyright $\bigcirc 2021$ by authors, all rights reserved. Authors agree that this article remains permanently open access under the terms of the Creative Commons Attribution License 4.0 International License

\begin{abstract}
Objectives: The research aims to identify the level of institutional excellence in the Egyptian and Saudi football federations in view of the dimensions of the European Excellence Model EFQM. Methods: The researchers used the descriptive approach, following the survey method, to accommodate it with the nature and procedures of the research in order to achieve the goal of the research and answer its questions. Results: The overall score for the average application of the dimensions of the European Excellence Model EFQM in the Egyptian Football Association research sample is 1.84, which is in the intermediate level raise the level of administrative performance of the Egyptian Football Association through the application of the dimensions of the European Excellence Model EFQM. It is clear that the average level of application of the dimensions of the European Excellence Model EFQM in the Saudi Football Association is 2.41 . There are statistically significant differences between the averages of the answers about each of the Egyptian Football Association and the Saudi Football Federation in the application of the dimensions of the European Excellence Model EFQM and the overall degree of application of the dimensions of the European Excellence Model EFQM in favor of the Saudi Football
\end{abstract}

Association. It is also evident that there are no statistically significant differences between the average answers about both the Egyptian Football Association and the Saudi Football Association in the application of some partnerships and resources.

Keywords Egyptian Football Association, Saudi Football Association, European Excellence Model

\section{Introduction}

The management of sports institutions is witnessing successive changes and various transformations, forcing it to reconsider its method of work and its level of performance and move towards the application of modern administrative methods that guarantee its achievement of excellence at the individual and institutional group. Developing its services and activities by keeping pace with the rapid developments in technology and ensuring survival in a highly competitive environment in view of the globalization of sport and the knowledge economy. (John, 2006). 
Excellence management is one of the federations modern management methods on which different institutions depend. It is an integrated scientific approach that aims to set standards upon which the direction of institutions aims to achieve excellence in the services and activities provided. The European Model for Excellence (EFQM) is one of the global models in which different institutions rely on achieving institutional excellence at the local and international levels by applying its standards within the institution. It is a measurement method for the institution that determines if it is on the path of excellence and its contribution to identifying deficiencies and addressing them to improve its performance and can be applied in any institution regardless of its nature, size, and structure, as it does not need a complex procedure for its application. (Ghanem, 2012), (Alrkaf, 2019), (John, 2006).

The European Excellence Model (EFQM) is an administrative tool for measuring the performance of an institution of different nature through several criteria that are relied upon to achieve improvement in the work of that institution. It also contributes to identifying improvement plans that enable the institution to attain distinct results and a sustainable global competitive advantage because the model focuses on improving performance with a focus on customers as it seeks to achieve the best performance of the organization by involving all employees in the continuous improvement of operations, eliminating duplication, and achieving effective partnerships with all concerned within the organization. (Méndez Rial\& Gambau, 2014), (Patrícia, Carolina, 2020), (Alanazi, 2021), (Al-Selami, 2002).

The importance of achieving institutional excellence by relying on one of the global models of excellence, such as the European Model of Excellence (EFQM) in sports institutions, is embedded in opening new horizons for improvement and development. This is due to the rapid and successive changes that do not enable sports institutions to guarantee to achieve their goals by relying on a consistent methodology and identifying strengths and weaknesses. This contributes to defining modernization plans, increasing competitiveness and optimal utilization of available resources, as well as increasing the productivity of all elements of the sports institution to try to reach zero errors in the management of the institution, The European Model of Excellence (EFQM) seeks to develop administrative performance through self-evaluation, continuous improvement and providing an advantage sustainable competitiveness, it is one of the most common models of excellence used by different institutions, this is what prompted researchers to adopt this model in the current research, and the European Model of Excellence (EFQM) A set of basic principles relied upon in helping organizations develop and achieve sustainable excellence. Figure 1 illustrates these principles: (Tilman, 2021), (Kiraz, Açikgöz, 2021), (Martínez, Díaz Suárez, 2016), (Rivera, Benito, 2021), (Manresa, Escobar, 2021), (EFQM, 2012).

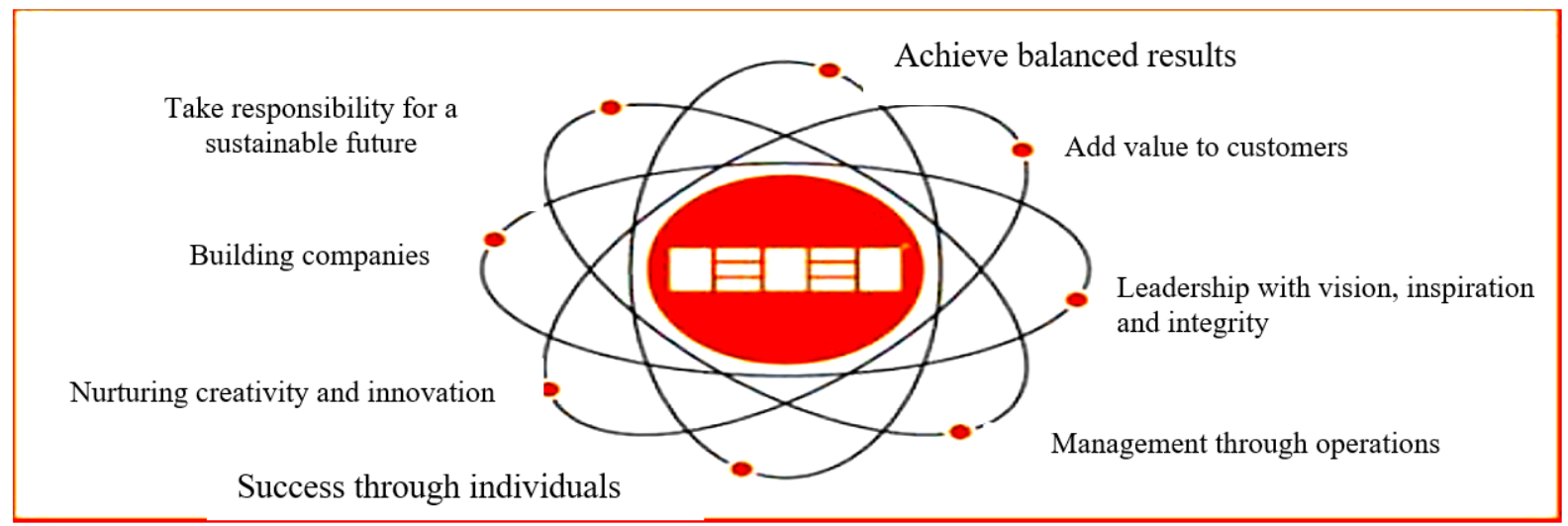

Figure 1. Fundamental principles of the European Excellence Model (EFQM) 
In addition, the European Excellence Model (EFQM) requires, when applied within institutions, several standards to ensure its effectiveness and achieve the many benefits desired from its application. These criteria are divided into two groups, the set of enablers includes five (5) standards, and the set of results are four (4):

The set of enablers refers to all the auxiliary elements that focus on the tasks required of the institution to perform and it includes five (5) criteria as listed below;

(a) Leadership: It means that the distinguished organization possesses leaders who can continuously improve the organization, and this is done by adopting a vision, mission, and values based on quality, motivation, and continuous support for workers and active participation in the development, application, and modernization of work systems.

(b) Leadership: It means that the distinguished organization possesses leaders who can continuously improve the organization, and this is done by adopting a vision, mission, and values based on quality, motivation, and continuous support for workers and active participation in the development, application, and modernization of work systems.

(c) Human Resources Management: It means that the distinguished organization works to develop the capabilities of its employees, promote the values of justice and equality among them, and achieve mutual benefit between its objectives and the personal interest of the workers. It also works to reward and appreciate them in a way that motivates them, enhances their commitment, and helps them use their skills and knowledge to achieve the planned goals.

(d) Human Resources Management: It means that the distinguished organization works to develop the capabilities of its employees, promote the values of justice and equality among them, and achieve mutual benefit between its objectives and the personal interest of the workers. It also works to reward and appreciate them in a way that motivates them, enhances their commitment, and helps them use their skills and knowledge to achieve the planned goals.

(e) Operations and Services Management: It means that the distinguished organization works to manage and improve operations to support its policies and strategy to meet the needs and expectations of the parties concerned and achieve its desired goals.

The second group, results, refers to what the institution achieves and accomplishes using methodologies, It includes four (4) criteria as follows:

(a) Service Recipient Satisfaction: This criterion is concerned with measuring the extent to which customers achieve and their level of satisfaction with the services provided.

(b) Employee Satisfaction: This dimension is concerned with measuring how results related to human resources are achieved and their satisfaction levels. (c) Community Service Results: This dimension is concerned with measuring the extent to which community results are achieved at the local, regional and global levels.

(d) Performance Results: This dimension is concerned with measuring how the results and achievements of the sports federation are achieved compared to the established plans and according to the policy and strategy based on the nature of work and objectives. (EFQM, 2013), (Turisová et al 2021), (Ángeles \& José Ángel, 2017), (Denkler, 2021), (Al-Tuwaijri, 2019), (Ibrahim, 2020), (Jankal, 2016), (Martín \& Escrig-Tena, 2018), (Ibrahim, 2020).

Sports federations are like the various bodies required to constantly search for unique administrative methods compatible with the modern era, which is consistent with the globalization of sport and the knowledge economy. This is to ensure the continuation of providing distinguished services and to be able to compete and achieve institutional excellence.

Looking at Egypt's vision 2030and Kingdom of Saudi Arabia vision 2030, we find that sport has an important role in achieving these visions and sports institutions that governments rely on to provide services and activities that are distinguished because this is reflected in the social and security system and the mental image of peoples' culture. This requires sports federations to strive towards the application of global administrative models that contribute to achieving the institutional excellence of the Sports Federation.

The Egyptian and Saudi football federations are among the essential federations due to the incredible popularity of football in Egypt and Saudi Arabia. Therefore, this federation requires the use of the latest administrative methods and global administrative models to achieve the goal of these federations, develop their activities, keep pace with global technological development and achieve institutional excellence for the sake of providing local competitions of quality and achieving the continental and global standard in the game of football. Accordingly, the trend towards institutional excellence for the Egyptian and Saudi football federations has become necessary to keep pace with the global competition for the football industry, which has become one of the important industries in the world.

By referring to the results and recommendations of previous studies related to the subject of the research, such as the study of Senussi (2019), which included among its results that the Egyptian Football Association suffers from a clear deficiency in administrative performance, this is reflected negatively on all competitions presented by the association, as the study of Abdel-Gawad (2018) also confirmed it. The Egyptian Football Association (EFA) suffers from several administrative, legislative, and technical obstacles that negatively affect organizational performance, necessitating modern executive models and 
the trend towards digital transformation. Abu Al-Enein (2017) also found that the Egyptian Football Association suffers from administrative problems related to regulations and organizing its competitions. The Al-Asmari study (2019) found that the Saudi Football Association continuously develops to reach managerial creativity and achieve institutional excellence. However, it needs more development to attain excellence, especially in the regulations governing professional players.

The study of Trébucq (2017), Khamis (2017), Mahmoud (2019), Hassan (2020), and Ibrahim (2020), Kiraz (2021), Tilman (2021), Manresa, Escobar (2021) indicated that the use of the European Excellence Model (EFQM) in various institutions contributes to assessing their conditions and is a starting point for development plans and achieving sustainable competitive advantage. This contributes to achieving institutional excellence, and through the results and recommendations of previous studies, the use of the European Excellence Model (EFQM) may contribute to assisting the Egyptian and Saudi Football Associations in evaluating their performance, developing a clear picture of their administrative level, providing a clear comparison between them, and contributing to defining plans. Development and achieving a sustainable global competitive advantage. Therefore, the current study seeks to identify the level of application of the European Excellence Model EFQM in the Egyptian and Saudi Football Federations to reach results that serve as a starting point for federations to achieve institutional excellence.

The research aims to identify the level of institutional excellence in the Egyptian and Saudi football federations in view of the dimensions of the European Excellence Model EFQM, by answering the following questions:

1. What is the level of application of the EFQM dimensions of the Egyptian Football Association?

2. What is the level of application of the EFQM dimensions of the Saudi Football Association?

3. Are there statistically significant differences between the average answers about both the Egyptian Football Association and the Saudi Football Association in implementing the dimensions of the European Excellence Model EFQM?

\section{Definition of Terms}

\section{a. Organizational Excellence}

The planned and organized efforts undertaken by the institution to achieve integration and interdependence, to reach the highest rates of effectiveness and the level of outputs that achieve the desired benefits and expectations of the stakeholders associated with the institution of clients and workers (Al-Selami, 2002).

b. Model European Foundation For Quality Management excellent EFQM.

A practical management tool for an integrated system of processes and procedures representing a clear work program and methodology that enables the organization to measure its performance in view of a set of criteria to identify and assist strengths and weaknesses. This has to be developed under an effective management system that guarantees organizations the achievement of continuous excellence through their practices. (Al-Omari, 2015).

\section{Materials and Methods}

The researchers used the descriptive approach, following the survey method, to accommodate it with the nature and procedures of the research to achieve the goal of the research and answer its questions.

The research community consists of the following:

(a) The research community of the Egyptian Football Association: The research community is represented by the tripartite committee for the management of the Egyptian Football Association and the staff of the various committees of the Egyptian Football Association.

(b) The research community of the Saudi Football Association: The research community is represented by the board of directors of the Saudi Football Association and workers in the various committees of the Saudi Football Association.

The research sample consists of the following:

(a) The research sample for the Egyptian Football Association

The researchers selected the research sample in a random manner from the tripartite committee for the management of the Egyptian Football Association, and the workers in the various committees of the Egyptian Football Association, where the total number reached (110) individuals distributed as follows:

\section{The Basic Sample}

Ninety-three (93) questionnaires were distributed to the members of the main sample, and Ninety-two (92) questionnaires were retrieved, with a rate of retrieval (response) by the sample members amounting to (98.92\%) and (80) questionnaires were approved, after excluding (12) questionnaires that were not valid for analysis. Due to the lack of information contained therein, the statistician and thus the final number of the basic sample became eighty (80) individuals.

\section{Pilot Study}

Thirty (30) questionnaires were distributed to the exploratory sample. This sample was from the same study population and outside the primary sample. Thirty (30) questionnaires were retrieved, subject to statistical 
analysis.

The final number of the research sample for the Egyptian Football Association (basic and exploratory) has become one hundred and ten (110) after counting the forms subject to statistical analysis.

(b) The research sample for the Saudi Football Association

The researchers selected the research sample, in an intentional, random manner, from the board of directors of the Saudi Football Association, and workers in the various committees of the Saudi Football Association, where the total number reached one hundred and ten (110) individuals distributed as follows:

\section{The Basic Sample}

Ninety-three (93) questionnaires were distributed to the members of the basic sample, and Ninety-three (93) questionnaires were retrieved, with a return rate (response) by the sample members amounting to $100 \%$, and eighty (80) questionnaires were approved, after excluding thirteen (13) forms that were not valid for analysis. The statistician due to the lack of information contained therein. Thus, the final number of the basic sample became (80) individuals.

\section{Pilot Study}

Thirty (30) questionnaires were distributed to the exploratory sample. This sample was from the same study population and outside the main sample, and (30) questionnaires were retrieved, subject to statistical analysis.

The final number of the research sample for the
Egyptian Football Association (basic and exploratory) has become (110) after listing the forms that are subject to statistical analysis, and table 1 shows that the total study sample is (220) equivalent to $100 \%$, and the total number of the research sample for the Egyptian Football Association (EFA) is (110) distributed (80) basic samples and (30) Pilot samples. Of the Saudi Football Association (110) distributors (80) basic samples and (30) Pilot samples.

In order to achieve the research objectives and collect its data, the researchers prepared a questionnaire on institutional excellence in the Egyptian and Saudi football federations in view of the EFQM European Excellence Model; It consists of (9) dimensions: the first dimension: leadership, the second dimension: policies and strategies, the third dimension: human resources management, the fourth dimension: partnerships and resources, the fifth dimension: operations and services management, the sixth dimension: the results of service recipient satisfaction, and the seventh dimension: satisfaction Union workers, the eighth dimension: the results of community service, the ninth dimension: performance results and a triple scale (agree, somewhat agree, disagree) was used.

In order to the criteria used in the research, the length of the cells was determined in the Triangular Likert scale by calculating the range between the questionnaire scores $(3-1=2)$ and then dividing it by the largest value in the questionnaire to get the length of the cell, i.e. $(2 / 3=0.66)$ and after This value was added to the lowest value in the questionnaire (the beginning of the questionnaire is a true one) in order to determine the upper limit of this cell, and thus the length of the cell became as shown in the table 2 .

Table 1. Characterization of the research sample

\begin{tabular}{|l|c|c|c|}
\hline \multicolumn{2}{|c|}{ Sample } & Number & Percentage \\
\hline \multirow{2}{*}{$\begin{array}{l}\text { 1- The research sample for the Egyptian Football } \\
\text { Association. }\end{array}$} & The basic sample & $\mathbf{8 0}$ & $\mathbf{3 6 . 3 6 \%}$ \\
\cline { 2 - 4 } & Exploratory sample & 30 & $13.64 \%$ \\
\hline \multirow{2}{*}{$\begin{array}{l}\text { 2- The research sample of the Saudi Football } \\
\text { Association. }\end{array}$} & The basic sample & 80 & $36.36 \%$ \\
\cline { 2 - 4 } & Exploratory sample & 30 & $13.64 \%$ \\
\hline \multicolumn{2}{|l|}{ Total } & 220 & $100 \%$ \\
\hline
\end{tabular}

Table 2. The criterion approved in the search

\begin{tabular}{|c|c|}
\hline Arithmetic mean & The criterion \\
\hline 1.66 in Less & Weak. \\
\hline From 1.67 to 2.33 & Average. \\
\hline from 2.34 and more & good. \\
\hline
\end{tabular}




\section{Scientific Transactions of the Questionnaire}

\section{(a) Content validity}

The researchers verified the content validity of the questionnaire, as the two questionnaires were presented to five (5) experts with experience and competence in the field of sports management from among the faculty members in order to verify the validity of the two questionnaire. They were asked to arbitrate in terms of

- Adequacy, comprehensiveness and objectivity of the two questionnaire.

- Ensuring the correct formulation and clarity of the questionnaire.

- Restatement, amendment, deletion or addition of axes and expressions that need to be done.

After collecting the questionnaire and reviewing the expert's observations, the wordings of some phrases of the two questionnaires were deleted and amended but did not obtain an approval rate of $80 \%$ or more, its content was reconstructed, and then it was presented to the same arbitrators. Once again, after making the required adjustments and meeting the approval rate of $100 \%$, which indicates that the tool has a high degree of validity of the content. Attachment (3) explains the procedures that have been taken to validate the content.

\section{(b) Internal consistency validity}

The researchers tested the validity of the questionnaire by applying them to an exploratory sample from the same research community and outside its core sample of thirty (30) individuals, and the validity of internal consistency was verified through statistically significant correlation coefficients between the degree of each statement and the total of the axis belonging to it and the total number of the questionnaire. The sum of each axis and the total sum of the questionnaire, as the calculated value of $(r)$ ranged between (66. - 89.), which is greater than its tabular value at a significant level of (0.05), which indicates the validity of the questionnaire form.

\section{(c) Reliable}

The researchers tested the stability of the questionnaire by applying them to an exploratory sample of the same research community and outside its core sample of thirty (30) individuals, and the stability of the questionnaire was verified as the variation of the reliability coefficient in the alpha method for the axes and for the questionnaire as a whole was $(83-89)$, which is a statistically significant function. At a level of significance (0.05), which indicates that the questionnaire form under investigation has a high degree of stability, and thus the questionnaire form in its final form has become applicable to the basic study sample.

\section{(d) The basic study}

The researchers designed the two questionnaires on
Google Forms and presented them to the research sample whose strength reached eighty (80) individuals for the sample of the Egyptian Football Association, and eighty (80) individuals for the sample of the Saudi Football Association, and that was during the period from $23 / 2 / 2021$ to $25 / 3 / 2021$.

\section{Results and Discussion}

The first question (Q1): What is the level of application of the EFQM dimensions of the Egyptian Football Association?

It is clear from Table (2) the average level of application of the dimensions of the European Excellence Model EFQM in the Egyptian Football Association (EFA) is (1.84), which is located at (the average level) according to the Likert scale.

By studying the results listed in Table 3 regarding the opinions of the research sample on identifying the level of application of the dimensions of the European Excellence Model EFQM in the Egyptian Football Association, the following is evident:

The overall score for the average application of the dimensions of the European Excellence Model EFQM in the Egyptian Football Association research sample is (1.84), which is in the intermediate level raise the level of administrative performance of the Egyptian Football Association through the application of the dimensions of the European Excellence Model EFQM as one of the global administrative methods in which the various institutions rely to achieve institutional excellence at the local, regional and international levels by applying its dimensions within the institution. The Road of Excellence and its contribution to identifying deficiencies and addressing them in order to improve their performance.

This is consistent with the study of Abu Al-Enein (2017), Abdel-Gawad (2018), and Senussi (2019) that the Egyptian Football Association administration suffers from many administrative obstacles, which is reflected negatively on the services provided by the Egyptian Football Association, which necessitates utilizing global management models that contribute effectively to developing performance and achieving institutional excellence.

In this regard, the study of Ibrahim (2020), Kiraz (2021), Tilman (2021), Manresa, Escobar (2021), recommended that the application of the EFQM dimensions within the institution contribute to the development of administrative performance and achieve excellence and leadership. For the institution, through self-evaluation and continuous development, as it is one of the most effective models for achieving excellence.

The second question (Q2): What is the level of application of the dimensions of the European Excellence Model EFQM in the Saudi Football Association? 
It is clear from Table (3) the average level of application of the dimensions of the European Excellence Model EFQM in the Saudi Football Association is (2.41), which is located at (the level is good) according to the triple Likert scale. By studying the results listed in Table 4 regarding the views of the research sample on identifying the level of application of the dimensions of the European Excellence Model EFQM in the Saudi Football Association, the following is evident:

The total score of the average application of the dimensions of the European Excellence Model EFQM in the Saudi Football Association research sample is (2.41) This is what is located at the (good level) and thus the management of the Saudi Football Association achieves institutional excellence at a good level and this is an indication that the Saudi Football Association applies the dimensions of the European Excellence Model EFQM as one of the global management methods in which the various institutions rely to achieve institutional excellence at the local, regional and international level, which reflected positively on the good administrative performance.

Table 3. The arithmetic mean and the percentage importance of the research sample responses about the model dimensions EFQM European Excellence for Egyptian Football Association

\begin{tabular}{|c|c|c|c|c|c|c|}
\hline No & $\begin{array}{c}\text { The dimensions of the European model of } \\
\text { excellence EFQM in the Egyptian Football } \\
\text { Association. }\end{array}$ & $\begin{array}{l}\text { Number } \\
\text { of items }\end{array}$ & $\begin{array}{l}\text { arithmetic } \\
\text { mean }\end{array}$ & $\begin{array}{l}\text { Importance } \\
\text { ratio }\end{array}$ & Arrangement & level \\
\hline 1 & The first dimension: leadership. & 11 & 1.80 & 60.04 & 6 & Average \\
\hline 2 & $\begin{array}{c}\text { The second dimension: policies and } \\
\text { strategies. }\end{array}$ & 8 & 1.68 & 55.89 & 8 & Average \\
\hline 3 & $\begin{array}{l}\text { The third dimension: human resource } \\
\text { management. }\end{array}$ & 8 & 1.93 & 64.06 & 2 & Average \\
\hline 4 & $\begin{array}{l}\text { The fourth dimension: partnerships and } \\
\text { resources. }\end{array}$ & 9 & 2.26 & 75.14 & 1 & Average \\
\hline 5 & $\begin{array}{l}\text { The fifth dimension: Operations and services } \\
\text { management. }\end{array}$ & 7 & 1.85 & 61.72 & 4 & Average \\
\hline 6 & $\begin{array}{l}\text { The sixth dimension: results of service } \\
\text { recipient satisfaction. }\end{array}$ & 6 & 1.90 & 63.20 & 3 & Average \\
\hline 7 & $\begin{array}{l}\text { The seventh dimension: satisfaction of union } \\
\text { workers. }\end{array}$ & 6 & 1.75 & 58.40 & 7 & Average \\
\hline 8 & $\begin{array}{l}\text { The eighth dimension: the results of } \\
\text { community service. }\end{array}$ & 5 & 1.56 & 52.17 & 9 & Weak \\
\hline 9 & The ninth dimension: performance results. & 7 & 1.83 & 60.83 & 5 & Average \\
\hline \multicolumn{2}{|c|}{$\begin{array}{l}\text { The overall score of the level of the application of the } \\
\text { dimensions of the European Excellence Model } \\
\text { EFQM in the Egyptian Football Association. }\end{array}$} & 67 & 1.84 & 61.27 & & Average \\
\hline
\end{tabular}

Table 4. The arithmetic mean and the percentage importance of the research sample responses about the model dimensions EFQM European Excellence in the Saudi Football Association

\begin{tabular}{|c|c|c|c|c|c|c|}
\hline No & $\begin{array}{l}\text { The dimensions of the European model of } \\
\text { excellence EFQM in the Saudi Football } \\
\text { Association. }\end{array}$ & $\begin{array}{l}\text { Number } \\
\text { of items }\end{array}$ & $\begin{array}{l}\text { Arithmetic } \\
\text { mean }\end{array}$ & $\begin{array}{l}\text { Importance } \\
\text { ratio }\end{array}$ & Arrangement & level \\
\hline 1 & The first dimension: leadership. & 11 & 2.41 & 80.11 & 6 & Good \\
\hline 2 & The second dimension: policies and strategies. & 8 & 2.40 & 79.90 & 7 & Good \\
\hline 3 & $\begin{array}{l}\text { The third dimension: human resource } \\
\text { management. }\end{array}$ & 8 & 2.36 & 78.64 & 9 & Good \\
\hline 4 & The fourth dimension: partnerships and resources. & 9 & 2.47 & 82.22 & 1 & Good \\
\hline 5 & $\begin{array}{l}\text { The fifth dimension: Operations and services } \\
\text { management. }\end{array}$ & 7 & 2.41 & 80.48 & 4 & Good \\
\hline 6 & $\begin{array}{l}\text { The sixth dimension: results of service recipient } \\
\text { satisfaction. }\end{array}$ & 6 & 2.41 & 80.28 & 5 & Good \\
\hline 7 & $\begin{array}{l}\text { The seventh dimension: satisfaction of union } \\
\text { workers. }\end{array}$ & 6 & 2.38 & 79.24 & 8 & Good \\
\hline 8 & $\begin{array}{l}\text { The eighth dimension: the results of community } \\
\text { service. }\end{array}$ & 5 & 2.45 & 81.58 & 2 & Good \\
\hline 9 & The ninth dimension: performance results. & 7 & 2.43 & 81.07 & 3 & Good \\
\hline \multicolumn{2}{|r|}{$\begin{array}{l}\text { The overall score of the level of application of the } \\
\text { dimensions of the European Excellence Model EFQM in } \\
\text { the Saudi Football Association. }\end{array}$} & 67 & 2.41 & 80.39 & & Good \\
\hline
\end{tabular}


This is in line with the study of Al-Asmari (2019) that the administration of the Saudi Football Association continuously strives to measure administrative performance to identify strengths and weaknesses in an effort to developplans for continuous modernization and work on the optimal use of resources. Available for that, it seeks to apply administrative methods and international models that have achieved successes, in line with the nature of the Saudi society, for the sake of development and excellence, and in a way that serves Saudi sport.

In this regard, the study of (Patrícia, Carolina, 2020), (Alanazi, 2021),(Rivera, Benito, 2021), (Manresa, Escobar, 2021) recommended that the application of the dimensions of the European Excellence Model EFQM within the institution achieves global competitive advantage and contributes effectively to the development of administrative performance because it can identify weaknesses within the administrative work and then facilitate the leadership within the institution to work on development plans, overcoming weaknesses and achieving institutional excellence.

The third question (Q3): Are there statistically significant differences between the averages of the answers to both the Egyptian Football Association and the Saudi Football Association in applying the dimensions of

\section{the European Excellence Model EFQM?}

Table 4 show that there are statistically significant differences between the averages of the answers about each of the Egyptian Football Association and the Saudi Football Association in the application of the dimensions of the European model For excellence EFQM and the overall score for applying the dimensions of the European Excellence Model EFQM in favor of the Saudi Football Association, as the calculated (t-value) is greater than the tabular as the (t-value) calculated is greater than the value (C) Scheduling at a level of morale (0.05), at a significant level of (0.05) i.e. the superiority of the Saudi Football Association over the Egyptian Football Association in the application of dimensions The European Model of Excellence (EFQM), except for the fourth dimension, partnerships and resources, where there are no statistically significant differences between the averages of the Egyptian Football Association and the Saudi Football Association for the dimension of partnerships and resources, where the calculated (t-value) was (1.30), which is less than the (t-value) The tables are at a level of significance (0.05), meaning that the answers of the Egyptian Football Association and the Saudi Football Association are close in applying the number of partnerships and resources in the federations.

Table 5. (t-value) test for the differences between average answers to both the Egyptian Football Association and the Saudi Football Association in applying the dimensions of the European Model of Excellence EFQM

\begin{tabular}{|c|c|c|c|c|c|}
\hline $\begin{array}{c}\text { Dimensions of the European Model of } \\
\text { Excellence EFQM }\end{array}$ & $\begin{array}{l}\text { Egyptian and Saudi } \\
\text { Football Association }\end{array}$ & $\begin{array}{c}\text { Arithmetic } \\
\text { mean }\end{array}$ & $\begin{array}{l}\text { Standard } \\
\text { deviation }\end{array}$ & $\begin{array}{c}\text { T- } \\
\text { value }\end{array}$ & $\begin{array}{c}\text { Path coefficient } \\
\text { (Significant level) }\end{array}$ \\
\hline \multirow[t]{2}{*}{ The first dimension: leadership. } & $\begin{array}{l}\text { Egyptian Football } \\
\text { Association }\end{array}$ & 19.81 & 8.25 & \multirow[t]{2}{*}{3.99} & \multirow[t]{2}{*}{0.00} \\
\hline & Saudi Football Federation & 26.51 & 12.55 & & \\
\hline \multirow{2}{*}{$\begin{array}{c}\text { The second dimension: policies and } \\
\text { strategies. }\end{array}$} & $\begin{array}{l}\text { Egyptian Football } \\
\text { Association }\end{array}$ & 13.44 & 5.48 & \multirow[t]{2}{*}{5.49} & \multirow[t]{2}{*}{0.00} \\
\hline & Saudi Football Federation & 19.20 & 7.61 & & \\
\hline \multirow{2}{*}{$\begin{array}{l}\text { The third dimension: human resource } \\
\text { management. }\end{array}$} & $\begin{array}{l}\text { Egyptian Football } \\
\text { Association } \\
\end{array}$ & 15.44 & 7.83 & \multirow[t]{2}{*}{2.90} & \multirow[t]{2}{*}{0.04} \\
\hline & Saudi Football Federation & 18.88 & 7.12 & & \\
\hline \multirow{2}{*}{$\begin{array}{l}\text { The fourth dimension: partnerships and } \\
\text { resources. }\end{array}$} & $\begin{array}{l}\text { Egyptian Football } \\
\text { Association } \\
\end{array}$ & 20.34 & 8.81 & \multirow[t]{2}{*}{1.30} & \multirow[t]{2}{*}{0.19} \\
\hline & Saudi Football Federation & 22.23 & 9.61 & & \\
\hline \multirow{2}{*}{$\begin{array}{l}\text { The fifth dimension: Operations and } \\
\text { services management. }\end{array}$} & $\begin{array}{l}\text { Egyptian Football } \\
\text { Association } \\
\end{array}$ & 12.95 & 4.64 & \multirow[t]{2}{*}{3.47} & \multirow[t]{2}{*}{0.00} \\
\hline & Saudi Football Federation & 16.87 & 8.98 & & \\
\hline \multirow{2}{*}{$\begin{array}{l}\text { The sixth dimension: results of service } \\
\text { recipient satisfaction. }\end{array}$} & $\begin{array}{l}\text { Egyptian Football } \\
\text { Association } \\
\end{array}$ & 11.40 & 1.57 & \multirow[t]{2}{*}{4.09} & \multirow[t]{2}{*}{0.00} \\
\hline & Saudi Football Federation & 14.46 & 6.49 & & \\
\hline \multirow{2}{*}{$\begin{array}{l}\text { The seventh dimension: satisfaction of } \\
\text { union workers. }\end{array}$} & $\begin{array}{l}\text { Egyptian Football } \\
\text { Association } \\
\end{array}$ & 10.50 & 2.17 & \multirow[t]{2}{*}{5.14} & \multirow[t]{2}{*}{0.00} \\
\hline & Saudi Football Federation & 14.28 & 6.23 & & \\
\hline \multirow{2}{*}{$\begin{array}{l}\text { The eighth dimension: the results of } \\
\text { community service. }\end{array}$} & $\begin{array}{c}\text { Egyptian Football } \\
\text { Association }\end{array}$ & 7.80 & 1.80 & \multirow[t]{2}{*}{25.28} & \multirow[t]{2}{*}{0.00} \\
\hline & Saudi Football Federation & 12.25 & 1.34 & & \\
\hline \multirow{2}{*}{$\begin{array}{c}\text { The ninth dimension: performance } \\
\text { results. }\end{array}$} & $\begin{array}{c}\text { Egyptian Football } \\
\text { Association }\end{array}$ & 12.81 & 3.02 & \multirow[t]{2}{*}{3.97} & \multirow[t]{2}{*}{0.00} \\
\hline & Saudi Football Federation & 17.01 & 8.96 & & \\
\hline \multirow{2}{*}{$\begin{array}{l}\text { The overall score for the application of } \\
\text { the dimensions of the European Model of } \\
\text { Excellence EFQM. }\end{array}$} & $\begin{array}{c}\text { Egyptian Football } \\
\text { Association }\end{array}$ & 124.49 & 29.63 & \multirow[t]{2}{*}{5.17} & \multirow[t]{2}{*}{0.00} \\
\hline & Saudi Football Federation & 161.69 & 57.17 & & \\
\hline
\end{tabular}

The $(\mathrm{t}-\mathrm{value})=(1.99)$ at a significant level $(0.05)$. 
Table 5 for the application of the $(\mathrm{T})$ test indicates the significance of the differences between the averages of the answers about both the Egyptian Football Association and the Saudi Football Association in the application of the dimensions of the European Model of Excellence EFQM as it is smaller than the level of statistical significance $(0.05)$ and that these differences are real and in favor of answers of the Saudi Football Association, except for the fourth dimension, partnerships and resources, where there are no statistically significant differences between the averages of the responses of the Egyptian Football Association and the Saudi Football Federation.

In view of the statistically significant differences between the average answers about both the Egyptian Football Association and the Saudi Football Federation in the application of the dimensions of the European Excellence Model EFQM and the overall degree of application of the dimensions of the European Excellence Model EFQM, the following is evident:

There are statistically significant differences between the averages of the answers about each of the Egyptian Football Association and the Saudi Football Federation in the application of the dimensions of the European Excellence Model EFQM and the overall degree of application of the dimensions of the European Excellence Model EFQM in favor of the Saudi Football Association, as the (t-value) calculated is greater than the value $(C)$ Scheduling at a level of morale (0.05), meaning the Saudi Football Federation surpassing the Egyptian Football Association in implementing the dimensions of the European Excellence Model EFQM, and this is due to the superiority of the Saudi Football Association management in the presence of an integrated strategy that expresses the current and future directions of the Federation as well. It works to develop it well and there is an organized contact between the employees which identifies the needs of the workers and seeks to satisfy these needs in a good way and to develop policies and strategies. This is in line with the results of the analysis of the internal and external environment for him as it develops future scenarios to face the potential changes that may challenge and focus on the needs of the current and future expectations of workers when developing their policies and strategies, as well as having performance indicators to identify the extent of implementation of policies and strategies developed by the Saudi Football Federation.

Also the existence of a bylaw in the Saudi Football Association that contributes to promoting the values of justice and equality among workers and holds professional development courses for its employees to develop their capabilities, and the administration of the Saudi Football Association excels in managing and improving operations in order to support its policies and strategy, as it benefits from feedback in order to develop operations in the federation with its branches and from the experiences of other local and international federations in developing the programs and activities of the Sports federation, The Saudi Football Federation is keen to have good relations with all sports clubs, it uses various scientific tools to measure the satisfaction of sports clubs with the services provided by the federation and to measure employee satisfaction. It also has indicators that contribute to measuring the quality of workers' productivity and the effectiveness of communication channels with their superiors in the Sports Federation. The administration of the Saudi Football Association excels in achieving the government's plan to spread the culture of sports practice and achieve sustainable development for society and the existence of indicators to measure the role of the Sports Federation in serving the community at the local, and regional levels, It is internationally based on scientific studies and research in order to develop the Sports Federation's plans for community service

It is also evident that there are no statistically significant differences between the average answers about both the Egyptian Football Association and the Saudi Football Association in the application of some partnerships and resources, as the calculated as the (t-value) calculated is greater than the value (C) Scheduling at a level of morale (0.05), is less than the tabular as the (t-value) calculated is greater than the value (C) Scheduling at a level of morale (0.05), at a significant level of (0.05), i.e. no existence of differences between the federations in the application of some partnerships and resources, and this is due to the fact that the Egyptian and Saudi federations need to reconsider the existing partnerships and forge new partnerships between the sports federation and other federations and various institutions at the local and international level, and that these partnerships support the federation's strategy and work to maximize the Federation's resources and making these resources a source of self-financing for the Federation.

\section{Conclusions}

1. The average application of the European Excellence Model EFQM in the Egyptian Football Association is (1.81), which is located at the Average level.

2. The average application of the European Excellence Model EFQM in the Saudi Football Association is (2.41), which falls at good level.

3. There are statistically significant differences between the average answers about both the Egyptian Football Association and the Saudi Football Association in the application of the dimensions of the European Excellence Model EFQM and the overall degree of application of the sizes of the European Excellence Model EFQM for the benefit of the Saudi Football Association except for the fourth dimension. In addition, there are statistically significant differences 
between the averages of the answers of the Egyptian Football Association and the Saudi Football Federation.

\section{Recommendations}

1. The Egyptian and Saudi Football Federation administrations should seek the help of specialists and experts to implement the dimensions of the European Excellence Model EFQM to ensure the success of its implementation.

2. To benefit from the current study that identified the strengths and weaknesses in the administrative performance of the Egyptian and Saudi federations by using the European Excellence Model EFQM as one of the global models to develop a perception that contributes to improving weaknesses and strengthening strengths.

3. Establish a specialized unit called "Institutional Excellence Unit" in sports institutions from experts in sports management working to familiarize themselves with all new methods and administrative models to implement what is appropriate with the sports institution and achieve its goals.

4. Conducting more studies to apply the EFQM European Excellence Model dimensions for managing various sports institutions as one of the global management models.

\section{Acknowledgements}

We are grateful to all participants in the study for their active cooperation.

\section{Conflict of Interest}

The authors declare that there are no conflicts of interest.

\section{REFERENCES}

[1] Abdel-Gawad, Haisem Saleh: (2018), obstacles to implementing digital transformation in the Egyptian Football Association in The light of determinants of the International Federation, Assiut Journal of Physical Education Sciences and Arts, No. 47, Part 4, Faculty of Physical Education, Assiut University.

[2] Abu Al-Enein, Sherif Mahmoud: (2017), The role of the Egyptian Football Association in activating club licenses Sports according to the requirements of the African Union, European Journal of Sport Science Technology, Issue 13, International Academy of Sport Technology https://ejsst.com/download_journals.php?id=18
[3] Alanazi, M.H. (2021), "Towards a further step in understanding business excellence models: a comparative approach", Benchmarking: An International Journal, Vol. ahead-of-print No. ahead-of-print. https://doi.org/10.1108/ BIJ-08-2020-0407

[4] Al-Asmari, Ali Muhammad. (2019), Administrative Empowerment and its Relationship to Creativity among Union Committees' employees Saudi Football Association, Reading and Knowledge Magazine, Issue No. 214, College of Education, Ain Shams University. https://doi.org/ 10.21608/mrk.2019.100166.

[5] Al-Omari, Hani Abdullah: (2015) Strategic planning concepts in light of the criteria for the Excellence Award 'Procedures and evaluation criteria, Riyadh, Saudi Council for Quality.

[6] AlRikf, Hind Bint Saleh: (2019), the reality of the application of Excellence Management for the Departments of Scientific Departments at the University Imam Muhammad bin Saud Islamic in the light of the standards of the European Model of Excellence EFQM, Journal Scientific Research in Education, Issue 2013, Girls' College of Arts, Sciences and Education, University Ain Shams. https://doi.org/10.21608/jsre.2019.71279.

[7] Al-Selami, Ali Muhammad: (2002) Management of Excellence, Models and Techniques of Management in the Age of Knowledge, Dar Gharib For printing, publishing and distribution, Cairo.

[8] Al-Tuwaijri, Fatima Bint Abdulaziz: (2019), The Department of Excellence in the Faculties of Education in Saudi Universities, according to The European Excellence Model: A Suggested Perception, The Future of Arab Education, No. 26, Part 123, Arab Center for Education and Development. http://journal.acedeg.org/AR/Journal/Study Details.aspx?ID=2671

[9] Denkler, T. (2021), Accreditation in Europe: Benchmarking the operations of European accreditation bodies using an innovative management tool. Accred Qual Assur 26, 47-57. https://doi.org/10.1007/s00769-021-01459-7

[10] EFQM. (2012). EFQM EXCELLENCE MODEL. Belgium. The European For Quality Management (EFQM). http://www.efqm.pt/\#CriteriaPTGhanem, Majid: (2012). An introduction to the European Excellence Model EFQM, Elite Management Consulting, Ramallah, Palestine.

[11] Hassan, Abdel Moneim El Desouky (2021). Requirements for managing excellence in secondary schools in Port Said governorate according to the European Excellence Model EFQM, a field study. 30, 538-539, Journal of Management Educational, Egyptian Association for Comparative Education and Educational Administration. http://doi.org/10.21608/emj.2021.164703.

[12] Ibrahim, Mohamed Hussein: (2020), A proposal for the management of institutional excellence in the Egyptian Tennis Federation The Light of the EFQM Standards, Assiut Journal of Physical Education Sciences and Arts, Issue 54, Part 1, Faculty of Physical Education, Assiut University, https://doi.org/10.21608/jprr.2020.118816.

[13] Jankal, Radoslav(2016), The application of The EFQM Excellence Model by the evaluation of Corporate Social Responsibility activities of companies, Procedia Economics and Finance, 39, 660-667. https://doi.org/10.1016/S2212-5 


\section{1(16)30313-6}

[14] John, Regan: (2006), Active Divisions Building and Promoting Cultures of Excellence in Academic Programs, translation Thaer Deeb Obeikan Library, Saudi Arabia.

[15] Khamis, Afka Saeed. (2017). Pictures of a proposal to manage organizational excellence in private schools in Alexandria governorate according to the European Excellence Model (EFQM) Issue 14, 389-581, Journal of Educational Administration, Egyptian Association for Comparative Education and Educational Administration. https://doi.org/ 10.21608/emj.2017.92524

[16] Kiraz, A., Açikgöz, N. A,(2021), A fuzzy-logic-based approach to the EFQM model for performance enhancement, SADHANA - Academy Proceedings in Engineering Sciences, 46, 43, https://doi.org/10.1007/s120 46-021-01576-6

[17] Mahmoud, Dalia Taha (2019). The requirements of Excellence in Management at Minia University according to the model, the European Foundation for Quality Management, EFQM, Issue 22, 281- 357, Journal of Educational Administration, Egyptian Association for Comparative Education and Educational Administration. https://doi.org/ 10.21608/emj.2019.92493.

[18] $M^{\mathrm{a}}$ Ángeles Iglesias Madrigal \& José Ángel Sanz Lara (2017) Applying the EFQM model to golf course management, Journal of Sport \& Tourism, 21:3, 223-241, https://doi.org/10.1080/14775085.2017.1338159

[19] Manresa, A.; Escobar Rivera, D. (2021), Excellence in Sustainable Management in a Changing Environment. Sustainability, 13(4), 2296; https://doi.org/10.3390/su1304 2296.

[20] Martínez-Moreno, A., Díaz Suárez, (2016), A. Level of quality management in the Municipal Sports Services, contrast trough EFQM Excellence Model. SpringerPlus 5, 1855https://doi.org/10.1186/s40064-016-3549-7.

[21] Martín-Gaitero, J.P. and Escrig-Tena, A.B. (2018), "The relationship between EFQM levels of excellence and CSR development", International Journal of Quality \&
Reliability Management, Vol. 35 No. 6, pp. 1158-1176. https://doi.org/10.1108/IJQRM-11-2016-0190.

[22] Méndez Rial, B., Cancela Carral, J. M., \& Gambau i Pinasa, V. (2014). Design and Psychometric Properties of the Questionnaire for Assessing Quality Management in Sports Federations. Apunts. Educación Físicay Deportes, 117 69-76. https://doi.org/10.5672/apunts.2014-0983.es.(2014/ 3).117.07.

[23] Patrícia Moura e Sáa, Carolina Fernandes. (2020), An assessment of a municipal physical activity programme for seniors based on the EFQM model: Integrating the views of internal and externalstakeholders, journal Evaluation and Program Planning, 80, 1-10. https://doi.org/10.1016/j.evalp rogplan.2020.101796.

[24] Rivera, D.E.; Terradellas Piferrer, M.R.; Benito Mundet, M.H. (2021), Measuring Territorial Social Responsibility and Sustainability Using the EFQM Excellence Model. Sustainability, 13(4), 2153; https://doi.org/10.3390/su1304 2153.

[25] Tilman Denkler. (2021), Accreditation in Europe: benchmarking the operations of European accreditation bodies using an innovative management tool, Accreditation and Quality Assurance, 26, pages 47-57, https://doi.org/10.1007/s00769-021- 01459-7.

[26] Trébucq, Stéphane, (2017), Using the EFQM excellence model for integrated reporting a qualitative exploration and evaluation, Research in International Business and Finance, Vol 42, 522 531, https://doi.org/10.1016/j.ribaf.2017.04.00 8.

[27] Turisová, R.; Pa caiová, H.; Kotianová, Z.; Nagyová, A.; Hovanec, M.; Korba, P.(2021), Evaluation of eMaintenance Application Based on the New Version of the EFQM Model. Sustainability 2021, 13, 3682. https://doi.org/10.3390/su13 073682 .

[28] Senussi, Lubna Mahmoud: (2019), evaluating the role of administrative reform strategies in improving the level of The Egyptian Football Association Performance, The Scientific Journal of Sports Science and Arts, No. 52, College of Education Sports for Girls, Helwan University. 